\title{
順序制約下での多項分布比較の 一方法と数表
}

会田 雅人 広津 千尋

総理府統計局 東大工学部

\begin{abstract}
要 旨 カテゴリーに自然な順序がある多項分布比較のための検定として は順位和に基ぶく Kruscal-Wallis 検定や累積カイ二乗法が提案され，そ の性質がいるいる調べられている（たとえば竹内・広津［6]）。これらは いずれも総括的な指向性険定として高い検出力を有するが，データ解析の より实際的な手段である多重比較の目的のなめには必ずしも適当でない。 本論文では，累積カイ二乗のある最大成分を用いる多重比較法適用のため の数表を与充，あわせて他の総括的な検定と検出力を比較することにより その有用性を評価する．検出力の検討の結果は，この方法が総括的な検定 としても累積カイ二乘法とほぼ同等であることを示している。なお，本論 文で採用した方法では限られた笧囲の数表しか作製できなかった．手法の 有用性はある程度示せたと思うので今後他のアプローチによる数表の整備 が望まれる。

Key words : Contingency Table, Cumulative Chi-squared, Wishart Distribution
\end{abstract}

\section{1. 順序制約下での多項分布比較}

$a$ 本の $b$ 項分布について，各七ルの出現確率を $P_{t y}$ とする $(1 \leqq i \leqq a, 1 \leqq j \leqq$ $\left.b, P_{i}=1\right)$. この場合, 多項分布の一様性の㷌無仮説は次の上5に書ける. $H_{0}$ : $P_{\imath \jmath}=P_{h j}, 1 \leqq i, h \leqq a, 1 \leqq j \leqq b$. ここで， $P_{i j}$ に対して次の変換を考光る.

$$
\left\{\begin{array}{l}
\phi_{j^{\prime}}=\log \left(P_{a j^{\prime}} / P_{a b}\right), 1 \leqq j^{\prime} \leqq b-1, \\
\lambda_{i^{\prime} j^{\prime}}=\log \left(P_{i^{\prime} j^{\prime}} P_{a b} / P_{i^{\prime} b} P_{a j^{\prime}}\right), \quad 1 \leqq i^{\prime} \leqq a-1,1 \leqq j^{\prime} \leqq b-1
\end{array}\right.
$$




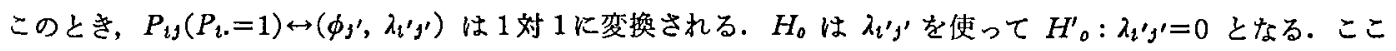
で $i$ 番目の多項分布の第 $j$ 番目の七ルの出現度数を $N_{i j}$ と特くと $N_{t j}$ の同時分布は

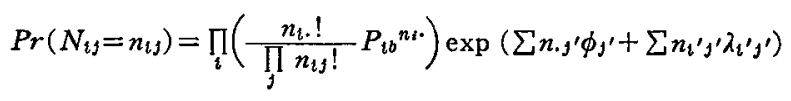

となり， $H_{0}^{\prime}$ の下での十分統計量は $n . ., n . j^{\prime}$ で完備である. そこで相似検定を構成するために, $n . ., n . g^{\prime}\left(j^{\prime}=1 \sim\right.$ $b$-1）が与兄られた下での条件付分布を求めると多項一般超幾何分布

$$
\text { const. } \frac{\exp \sum \sum n_{i^{\prime} g^{\prime} \lambda_{t^{\prime}} j^{\prime}}}{\prod n_{i j} !}
$$

となる. また， $H_{0}\left(=H_{0}{ }^{\prime}\right)$ の下では $N_{i j}$ の分布は多項超幾何分布となる.

$$
\frac{\left(\prod n_{\imath}, !\right)\left(\prod n_{. j} !\right)}{n . ! \prod n_{\imath} !}
$$

多項分布の水準に自然な順序がある場合，一様性の帰無仮説に対して対立仮説は次のようなものが想定され る.たとえば，同種類の製品を生産する $a$ 個の工程の優劣を知るのに，第 $i$ 工程から 1 個の製品をとるとき，第 $j$ 級に入る確率を $p_{\imath j}(1 \leqq i \leqq a ; 1 \leqq j \leqq b)$ とすると，一様性の帰無仮説 $H_{0}$ に対する興味ある対立仮説として

$$
\begin{aligned}
H_{A}: p_{i j} / p_{h j} & \gtreqless p_{i j+1} / p_{h j+1} \\
& (1 \leqq i, h \leqq a, 1 \leqq j \leqq b-1)
\end{aligned}
$$

が考えられる.これは第 $i$ 工程が第 $h$ 工程より優れる（劣る）ことに対応する.これに対し通常の適合度カイ二 乘検定は優劣比較には対応しない. $H_{A}$ を $\lambda_{t^{\prime} j^{\prime}}$ 使って

$$
\begin{gathered}
H_{A^{\prime}}: \lambda_{i^{\prime} \jmath^{\prime}}-\lambda_{h^{\prime} j^{\prime}}-\lambda_{i^{\prime} \jmath^{\prime}+1}+\lambda_{h^{\prime} j^{\prime}+1}(\gtreqless) 0 \\
1 \leqq i^{\prime}, h^{\prime} \leqq a-1, \quad 1 \leqq j^{\prime} \leqq b-1
\end{gathered}
$$

と表わすことができるただし， $\lambda_{t^{\prime} b}=0$ と定義する。

以下では $a$ 本の $b$ 項分布と列に自然な順序のある $a \times b$ の分割表を同一視する. これは，分割諘で行和 $n_{b}$, 列和 n.gが与えられた条件付分布と（1.1）が同じなるからである.

\section{2. 検定統計量}

順序制約下での多項分布比較に括いて，一様性の㷌無仮説に対して前述の対立仮説の方向への指向性のある検 定統計量は次のようなものが考光られる. 統計量の表現のために次のように記号を導入する. $a$ 本の $b$ 項分布を 並べて $a \times b$ の 2 元表としたときの出現度数 $N_{i j}$ の行和，列和のベクトルを

$$
\begin{aligned}
& \boldsymbol{r}^{\prime}=n_{. .}^{-1 / 2}\left(\sqrt{n_{1}}, \cdots, \sqrt{n_{\imath}}, \cdots, \sqrt{n_{a}}\right) \\
& c^{\prime}=n .^{-1 / 2}\left(\sqrt{n_{.1}}, \cdots, \sqrt{n_{. j}}, \cdots, \sqrt{n_{. b}}\right)
\end{aligned}
$$

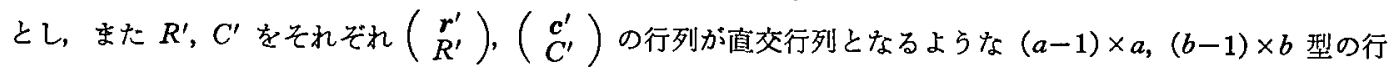
列とする.また $C^{* \prime}$ の第 $\left(j^{\prime}, j\right)$ 要素を

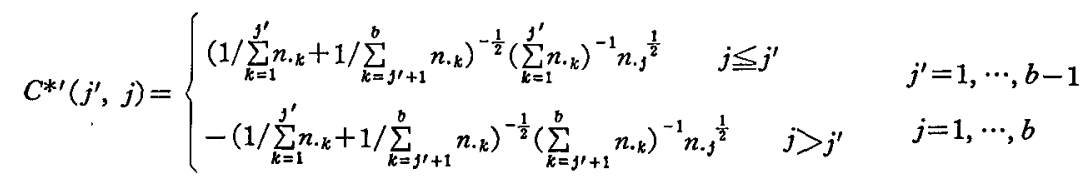

とする。 
また, $Z^{\prime}=\left(Z_{11}, Z_{12}, \cdots, Z_{1 b}, Z_{21}, \cdots, Z_{2 b}, \cdots, Z_{a 1}, \cdots, Z_{a b}\right), Z_{t j}=N_{t j} / \sqrt{n_{1 \cdot n .9} / n_{. .}}$とする.

このとき，各検定統計量は Kronecker 積を使って次のようと表現できる．参考のため通常の適合度カイ二乗 あ与えておく.

(i) 適合度为イ二乗

$$
\chi^{2}=\left\|\left(R^{\prime} \otimes C^{\prime}\right) Z\right\|^{2}
$$

(ii）順位検定

$$
T=\left\|\left(R^{\prime} \otimes \tilde{\boldsymbol{S}}\right) \boldsymbol{Z}\right\|^{2}
$$

$\tilde{\boldsymbol{S}}$ は適当な荷重ヘクトル $\boldsymbol{S}$ を基にして $\boldsymbol{C}^{\prime} \cdot \tilde{\boldsymbol{S}}=0,\|\tilde{\boldsymbol{S}}\|=1$ と規準化したもの. $\tilde{\boldsymbol{S}}^{\prime}=\left(S_{j}\right)$ 飞は $S_{1} \geq S_{2} \geq \cdots \geq$

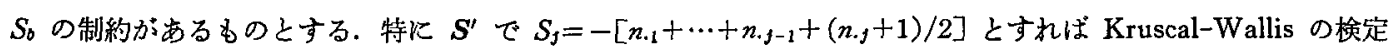
になる. $T$ の漸近分布は自由度 $(a-1)$ のカイ二乗分布になる.

(iii）累積カイ二乗

$$
\chi^{* 2}=\left\|\left(R^{\prime} \otimes C^{* \prime}\right) \boldsymbol{Z}\right\|^{2}
$$

漸近分布は平均と分散がそれぞれ $(a-1)(b-1), 2(a-1) \operatorname{tr}\left(C^{* \prime} C^{*}\right)^{2}$ となるように自由度 $f$ と定数 $d$ で調整し たカイ二乗 $d \chi^{2}(f)$ によりよく近似できる（竹内・広津 $\left.[6]\right)$.

(iv) 統計量 $\lambda$

$$
\begin{gathered}
\lambda=\underset{\gamma}{\max }\left\|\left(\boldsymbol{\gamma}^{\prime} \otimes C^{* \prime}\right) Z\right\|^{2} \\
\boldsymbol{\gamma}^{\prime} \cdot \boldsymbol{r}=0 \\
\|\boldsymbol{\gamma}\|^{2}=1
\end{gathered}
$$

この統計量は広津[7〕により提案されたもので，累積カイ二乗の最大成分を統計量とするすのであり，帰無仮 説の下での漸近分布は $a \geq b$ のとき, $W_{b-1}\left(C^{* \prime} C^{*}, a-1\right)$ の Wishart 分布に従ら行列の最大固有根の分布にな る. その証明は広津 $[7]$, p. 102 と同様炕きる.

\section{Wishart 行列の最大固有根の分布}

一般に $X=\left[\boldsymbol{x}_{1}, \cdots, \boldsymbol{x}_{n}\right]_{m \times n}, M=\left[\boldsymbol{m}_{1}, \cdots, \boldsymbol{m}_{n}\right]_{m \times n}, \operatorname{rank}(M)=m$ kおいて, $\boldsymbol{x}_{i}$ \& $E\left[\boldsymbol{x}_{i}\right]=\boldsymbol{m}_{i}, V\left[\boldsymbol{x}_{i}\right]=\Sigma$ の $m$ 次元正規分布に従い，かつ互いに独立とする。このとき $S=X X^{\prime}$ をWishart 行列といい

$$
S \sim W(\Sigma, n, \Omega) \quad\left(\Omega=\frac{1}{2} \Sigma^{-1} M M^{\prime}\right)
$$

之表わす. $n$ : 自由度 $\Omega$ : 非心母数行列.

$S$ の最大固有根の分布に関するパーセント点を以下で求める. ただし $M=O$ とし,

(1) $m=2$ のとき, $\Sigma=\left(\begin{array}{ll}1 & \rho \\ \rho & 1\end{array}\right)$ の形で $n=2 \sim 20$,

(3) $m=3$ のとを, $\Sigma$ の固有根 $\omega_{1} \geq \omega_{2} \geq \omega_{3}$ とし， $n=3 \sim 10$ の場合を扱う.（前述の多項分布比較の $a, b$ と は $a-1=n, b-1=m$ と対応する.)

最大根の分布関数は Sugiyama[4]で与えられていて， $\lambda_{1}$ : 最大固有根とすると，

$$
F\left(\lambda_{1}<\lambda_{0}\right)=\frac{|\Sigma|^{-\frac{n}{2}} \Gamma_{m}\left(\frac{m+1}{2}\right)}{2^{\frac{m n}{2}} \Gamma_{m}\left(\frac{m+n+1}{2}\right)} \exp \left(-\frac{\lambda_{0}}{2} \operatorname{tr} \Sigma^{-1}\right) \lambda_{0}^{\frac{m n}{2}} \cdot{ }_{1} F_{1}\left(\frac{m+1}{2} ; \frac{m+n+1}{2} ;-\frac{\lambda_{0}}{2} \Sigma^{-1}\right)
$$

となる・ただし， 
${ }_{1} F_{1}$ は超幾何級数で

$$
{ }_{1} F_{1}(a ; b ; S)=\sum_{k=0}^{\infty} \sum_{k} \frac{(a)_{k}}{(b)_{k}} \frac{C_{k}(S)}{k !}
$$

と表現される， $\sum_{\boldsymbol{r}}$ はに対する分割 $\kappa$ すべてでの和をとることである． $C_{\boldsymbol{x}}(S)$ は $S$ の要素を変数とする，分割 にに対する zonal 多項式である. その他記号については James[1]等を参照.

zonal 多項式は行列要素を成分とする多項式であり，行列に直交变換を行っても不变な式である.この多項式 で実際の值を求めるのには種々の方法があるが， $m \geq 3$ の場合は㷌納的に求める場合が多く，計算途中減算の 少ないす法が望ましいそこで James による，Laplace-Beltrami 作用素の固有関数としての性質を使っての方 法により計算を行った。

(i) $m=2$ のとき

（3.1）式の超幾何級数の各項が陽に表現できる.つ方 zonal 多項式が䚻納的な形によらず得られる（James [2]).このとき， $\lambda_{1}$ の上側 $5 \%$ 点と $1 \%$ 点を $\rho=0 \sim 0.8$ まで, また $n=2 \sim 6,8,10,15,20$ の組合せで求め た. 各値は小数以下第 4 位迄の精度を得るため場合に応じて超幾何級数の第 100 項，第 120 項，第 150 項迄の有 限項を使い求めた。計算は東京大学の大型計算機 M-200H を使用し，倍精度による（表 3.1).

\section{表 3.1 最大根の分布のパーセント点}

\begin{tabular}{|c|c|c|c|c|c|c|c|c|c|}
\hline \multicolumn{10}{|c|}{$m=2$} \\
\hline$n$ & 0.0 & 0.1 & 0.2 & 0.3 & 0.4 & 0.5 & 0.6 & 0.7 & 0.8 \\
\hline \multirow[t]{2}{*}{2} & 8. 5949 & 8.6365 & 8.7627 & 8.9763 & 9. 2758 & 9.6484 & 10.0722 & 10.5272 & 11.0010 \\
\hline & 12. 1602 & 12. 2711 & 12.5950 & 13. 1016 & 13. 7392 & 14. 4547 & 15. 2125 & 15. 9950 & 16. 7934 \\
\hline \multirow[t]{2}{*}{3} & 10.7403 & 10.8100 & 11. 0196 & 11. 3659 & 11.8320 & 12. 3854 & 12. 9915 & 13. 6280 & 14. 2834 \\
\hline & 14. 5681 & 14. 7283 & 15. 1884 & 15. 8857 & 16. 7332 & 17. 6608 & 18. 6304 & 19. 6250 & 20.6361 \\
\hline \multirow[t]{2}{*}{4} & 12. 6771 & 12. 7766 & 13. 0728 & 13. 5521 & 14. 1776 & 14. 8975 & 15.6703 & 16. 4732 & 17. 2953 \\
\hline & 16. 7268 & 16. 9363 & 17. 5293 & 18. 4051 & 19. 4433 & 20.5623 & 21.7235 & 22.9103 & 24. 1139 \\
\hline \multirow[t]{2}{*}{5} & 14.4883 & 14. 6194 & 15.0052 & 15.6176 & 16. 3968 & 17. 2744 & 18. 2045 & 19. 1648 & \\
\hline & 18. 7348 & 18. 9943 & 19. 7186 & 20.7648 & 21.9818 & 23. 2799 & 24. 6207 & 25.9875 & \\
\hline \multirow[t]{2}{*}{6} & 16. 2149 & 16. 3780 & 16.8558 & 17. 6013 & 18. 5296 & 19. 5585 & 20.6397 & 21. 7514 & \\
\hline & 20.6391 & 20.9493 & 21.8040 & 23. 0149 & 24.4023 & 25.8712 & 27. 3833 & 28. 9218 & \\
\hline \multirow[t]{2}{*}{8} & 19. 4917 & 19. 7234 & 20.3913 & 21.4017 & 22.6180 & 23. 9364 & 25. 3074 & 26.7094 & \\
\hline & 24. 2339 & 24.6479 & 25.7613 & 27. 2889 & 29. 0000 & 30.7935 & 32.6313 & 34. 4963 & \\
\hline \multirow[t]{2}{*}{10} & 22.6074 & 22. 9119 & 23. 7768 & 25.0496 & 26. 5433 & 28. 1396 & 29. 7890 & 31.4699 & \\
\hline & 27.6313 & 28.1521 & 29.5239 & 31.3544 & 33.3734 & 35.4760 & 37.6239 & 39. 7997 & \\
\hline \multirow[t]{2}{*}{15} & 29. 9651 & 30.4673 & 31.8450 & 33.7623 & 35. 9191 & 38. 1796 & 40.4947 & 42.8426 & \\
\hline & 35.5922 & 36. 3927 & 38.4038 & 40.9557 & 43.7029 & 46. 5366 & 49. 4177 & 52: 3279 & \\
\hline \multirow[t]{4}{*}{20} & 36.9412 & 37.6600 & 39.5697 & 42.1155 & 44.9084 & 47.8066 & 50.7607 & 53. 7486 & \\
\hline & 43. 0793 & 44. 1755 & 46. 8192 & 50.0578 & 53.4964 & 57.0236 & 60.5857 & & \\
\hline & $\{$ upper & $95 \%$ & & & & & & & \\
\hline & lower & $99 \%$ & & & & & & & \\
\hline
\end{tabular}

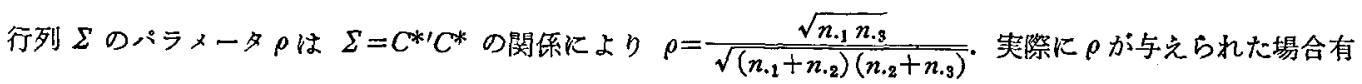


意点を，数表の補間により求めることができる。補間には表 3.1 を図 3.1 に例を示したようにプロットして求め るのが便利である.

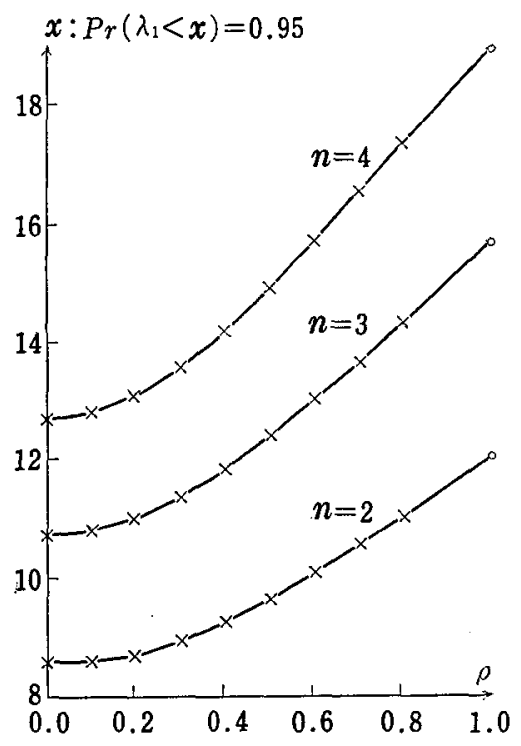

图 3.1

(ii) $m=3$ のとき

（3.1）式の級数の各項が陽には婊現できず帰納法による.zonal 多項式が Laplace-Beltrami 作用素の固有関数 になることから求めた（James[3])．数表を作成する場合には， $\omega_{1} \geq \omega_{2} \geq \omega_{3}$ とnの4つのパラィータが必要で。

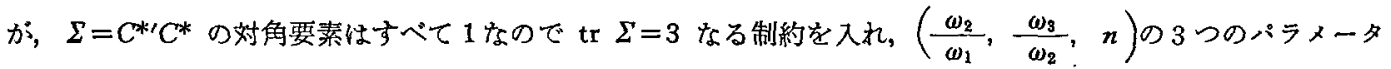
により作表した．小数第 2 位迄の精度を得るために超幾何級数の第 100 項，第 120 項までを使い求めた。（計算 機は $m=2$ の場合に同じ）しかし，nが大きくなるにつれ，または $\frac{\omega_{2}}{\omega_{1}}, \frac{\omega_{3}}{\omega_{2}}$ の值によっては第 120 項まで

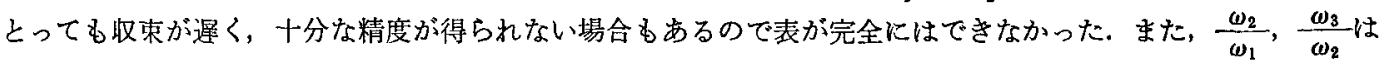

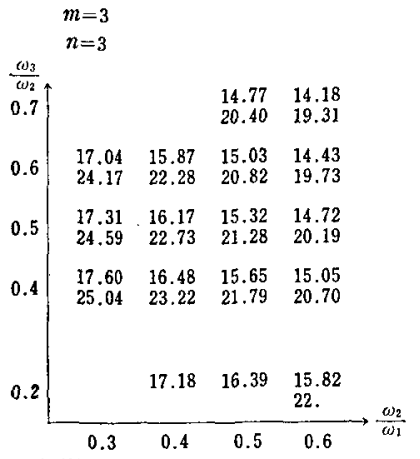

(補) 特别な柤合女

$1 . n_{1 .}=n .2=n_{.3}$ の埸合

$\left(\frac{\omega_{2}}{\omega_{1}}=0.33, \frac{\omega_{3}}{\omega_{2}}=0.5\right) \quad 16.89(\alpha=0.05)$

2. $\Sigma=I$ S(単位行列) 0 墫合

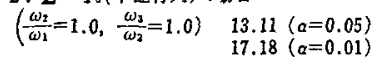

表 3.2

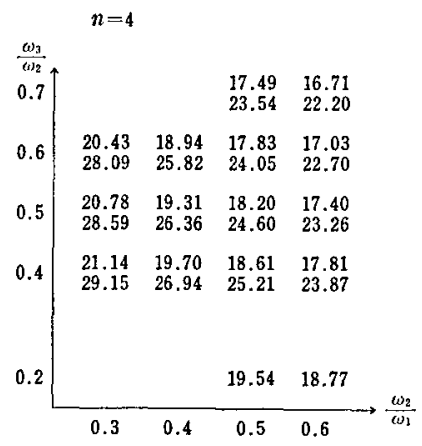

(補) 1 .

$\left(\frac{\omega_{2}}{\omega_{1}}=0.33, \frac{\omega_{3}}{\omega_{2}}=0.5\right) \begin{aligned} & 20.24(\alpha=0.05) \\ & 27.79(\alpha=0.01)\end{aligned}$

$\left(\frac{\omega_{2}}{\omega_{1}}=1.0, \frac{\omega_{3}}{\omega_{2}}=1.0\right) \quad \begin{aligned} & 15.24(\alpha=0.05) \\ & 19.50(\alpha=0.01)\end{aligned}$

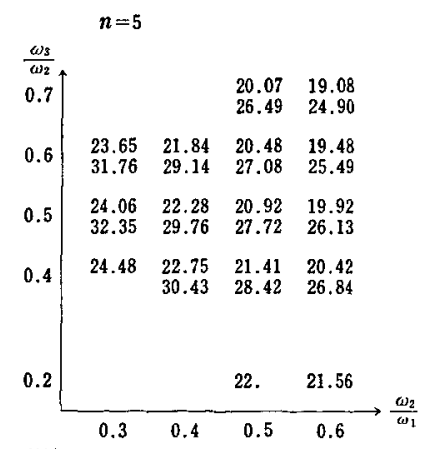

(補) 1 .

$\left(\frac{\omega_{2}}{\omega_{1}}=0.33, \frac{\omega_{3}}{\omega_{2}}=0.5\right) \begin{aligned} & 23.41(\alpha=0.05) \\ & 31.42(\alpha=0.01)\end{aligned}$

2.

$\left(\frac{\omega_{2}}{\omega_{1}}=1.0,-\frac{\omega_{3}}{\omega_{2}}=1.0\right) \quad \begin{aligned} & 17.22(\alpha=0.05) \\ & 21.66(\alpha=0.01)\end{aligned}$ 


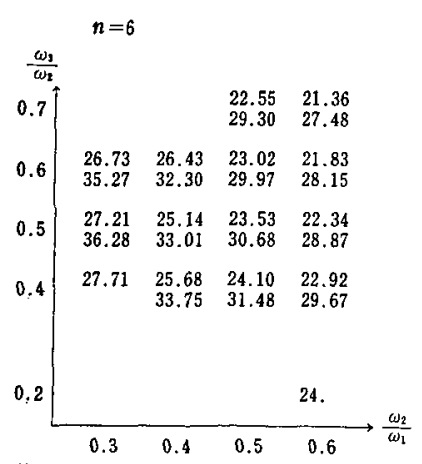

(補) 1 .

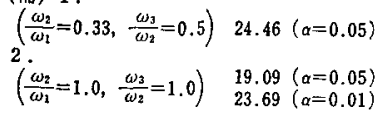

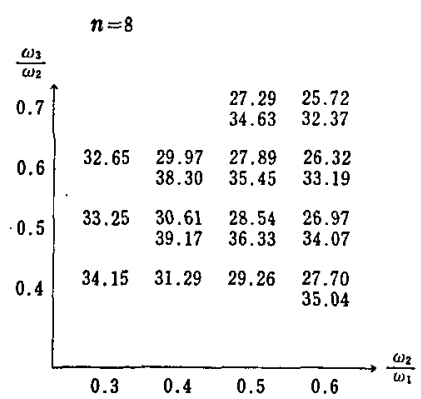

(補) 1 .

$\left(\frac{\omega_{2}}{\omega_{1}}=0.33, \frac{\omega_{3}}{\omega_{2}}=0.5\right) 32.30(\alpha=0.05)$ 2.

$\left(\frac{\omega_{2}}{\omega_{1}}=1.0, \frac{\omega_{3}}{\omega_{2}}=1.0\right) \quad 22.62(\alpha=0.05)$

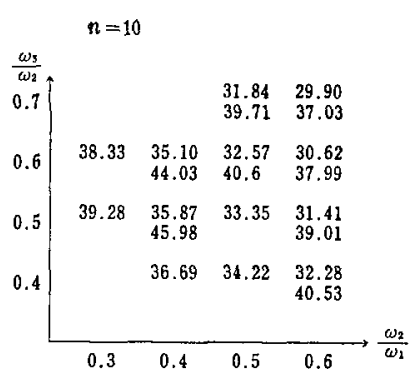

(補) 1 .

$\left(\frac{\omega_{2}}{\omega_{2}}=0.33, \frac{\omega_{3}}{\omega_{2}}=0.5\right) \quad 37.91 \quad(\alpha=0.05)$ 2 . $\left(\frac{\omega_{2}}{\omega_{1}}=1.0, \frac{\omega_{3}}{\omega_{2}}=1.0\right) \quad 25.96(\alpha=0.05)$

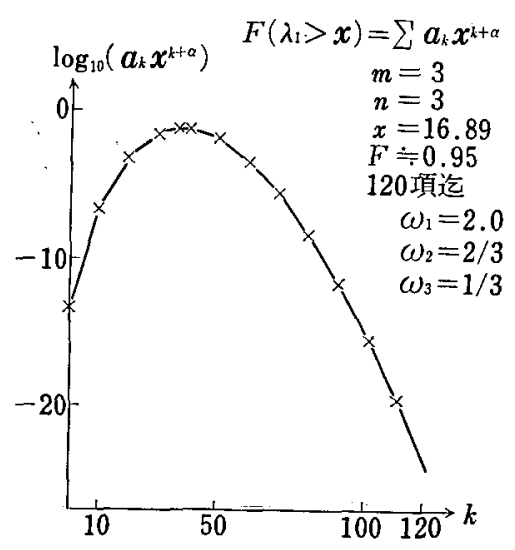

図 3.2

0〜1の笨田にあるわけだが，実際にいくつかの分割表を調べ，またいくつかの列和パターンを考えて調ペを結 果，洨3.2 亿与えたような範囲で穾用には有効であると判断した。それ以外については外捙により近似值を求め ればよい. 特に $\frac{\omega_{2}}{\omega_{1}}=\frac{1}{3}, \frac{\omega_{3}}{\omega_{2}}=\frac{1}{2}, n=3$ の場合に(3.1) 式の級数の各項の様子を図 3.2 に示す.

以上は漸近分布に基つくパーセント点であるが，この有用性をチェックするために， $a=b=3 ， n .=100$ で， 行和，列和のパターンを变えた場合の正確なパーセント点と比較した. そのため固定された周辺和に対して起り らるすべての 2 元表について出現確率と入の値を求め数え上ゲによりパーセント点を求めた (表 3.3). 表中 (10, 30 ，10）等が周辺和のパターンであり，その下の数字が漸近分布における5\%点である. 各セルの数值は，上段 が数え上げによる $5 \%$ 点，中段が平均と分散，下段が起りうる 2 元表の種類の総数である.たとえば，列和のパ ターンが (30，40，30）では各セルの期待頻度は5 10程度になり，漸近分布での $5 \%$ 点（9.35）は丰際のパー セント点（9.31 9.40）と0.5\%程度の相対誤盖である. また，列和のパターンが $(10 ， 10 ， 80)$ では，各セル の期待頻度は最小のるのは $2 \sim 3$ 程度と小さくなるが，このような場合でも漸近分布のパーセント点 (10.37) と 実際のパーセント点（10.11〜10.17）の相対誤差は $2.5 \%$ 程度であり, 漸近分布のパーセント点は十分に使用で きると考觉られる。 
表 3.3 漸近分布に基づく $5 \%$ 点の精度

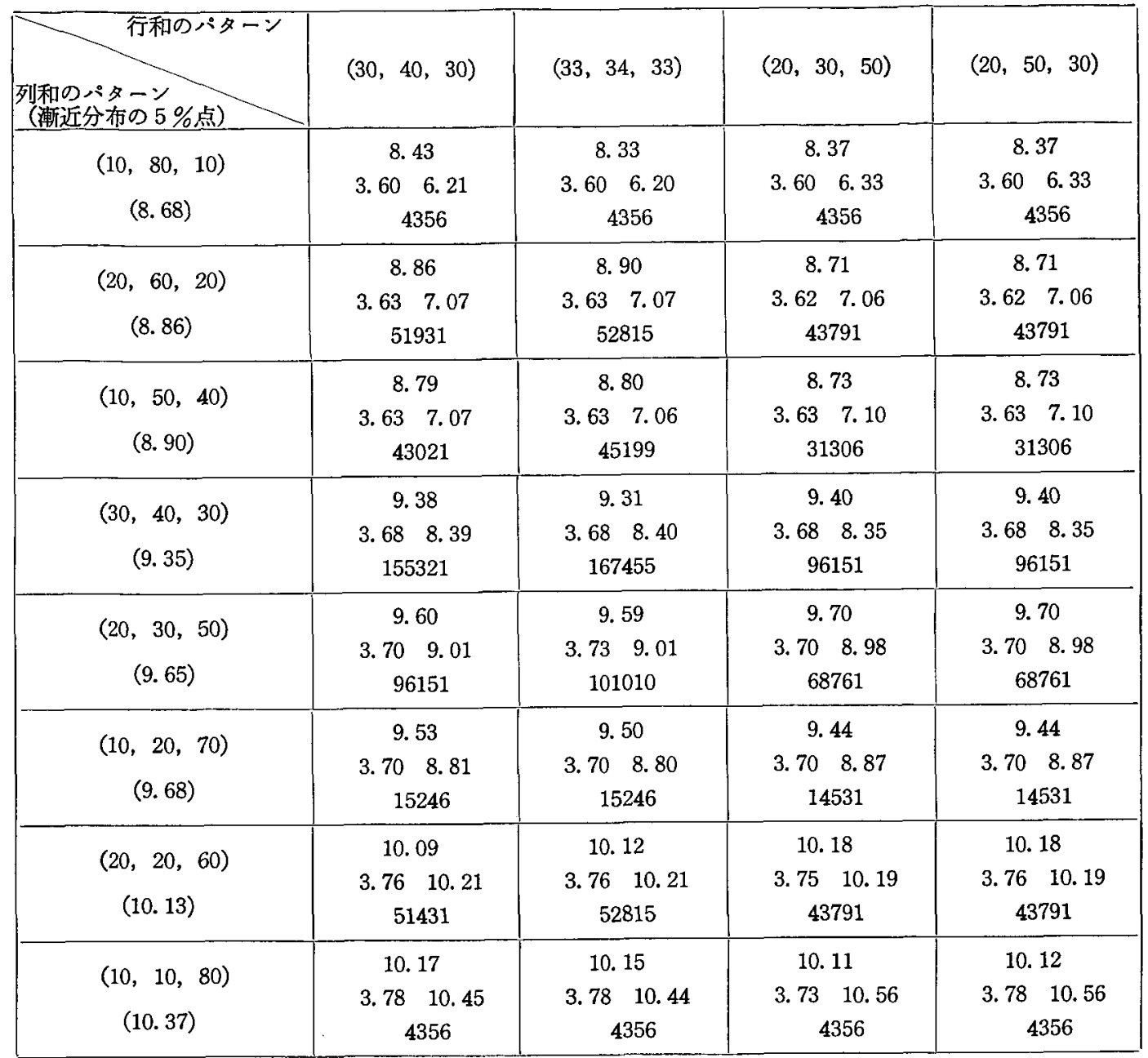

\section{4. 検出力の比較}

前述のと扮りスは累積カイ二乘の最大成分に対応する統計量である。順序制約のある列に関して，同じC゙を 使っているため，対立仮説の色ふなモデルに対する検出力は累積カイ二乗法と同じよらな傾向を示すと予想され る.

ここでは，適合度カイ二乗法，順位検定，累積カイ二乗法，入-法の検出力を比較する．対立仮説のモデルは広 津 $[7]$ Kならって分割表の背景に正規分布, 指数分布を仮定して構成した.

\section{[I] $3 \times 3$ の 2 元表に対して}

（a）正規分布を仮定する場合

まず $N\left(0,1^{2}\right)$ 江従う確率变数の累積確率が $1 / 3,2 / 3$ になる点を $U_{1}, U_{2}$ とする. 第 $i$ 行の確率 $q_{2 j}(j=1$, $\cdots, 3)$ は適当に $\mu_{i}$ を定め, $N\left(\mu_{l}, 1^{2}\right)$ に従う確索变数が区間 $\left(-\infty, U_{1}\right),\left(U_{1}, U_{2}\right),\left(U_{2}, \infty\right)$ に入る確率と 
して求める.このようにして作った $q_{l j}$ を以下のような二通りのやり方で分割表の確率 $p_{l j}$ に直す.

$a=3$ の場合

$$
\begin{aligned}
& \text { case } 1: p_{1 j}=q_{13} / 3, p_{2 j}=q_{2 j} / 3, p_{3 j}=q_{3 j} / 3 \\
& \text { case } 2: p_{1 j}=q_{1 j} / 5, p_{2 j}=q_{2 j} / 3, p_{3 j}=q_{3 j} / 2
\end{aligned}
$$

（b）指数分布を仮定する場合

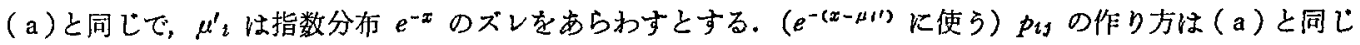
である.

対立仮説のモデル設定に用いる $\mu_{\imath}$ (正規分布仮定)， $\mu_{i}^{\prime}$ （指数分布仮定）は次のようにする.

$$
\begin{array}{ll}
A \text { (正規分布仮定) } & \mu=(0.0,0.2,0.5) \\
B \text { (正規分布仮定) } & \mu=(0.0,0.3,0.7) \\
C \text { (指数分布仮定) } & \mu^{\prime}=(0.0,0.1,0.2) \\
D \text { (指数分布仮定) } & \boldsymbol{\mu}^{\prime}=(0.0,0.2,0.35)
\end{array}
$$

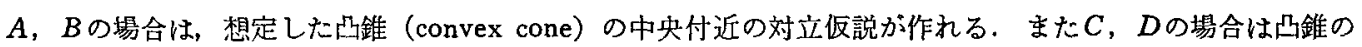
境界の（一段階だけ変化のある）対立仮説が作れる.

次に比較する検定統計量は, (i) ג-法, (ii) 累積カイ二乗 $\chi^{* 2}$ ，(iii）順位検定で $s=(3,2,1)$ ，(iv）KruscalWallis 検定，（v）適合度カイ二乗検定 $\chi^{2}$ とする.

表 4-1 は可能なすべての 2 元表に対して計算した正確な值で，表 4.2 は乱数を使ったシミュレーションによる

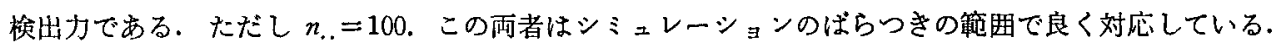

表 4.1 正確な分布での検出力

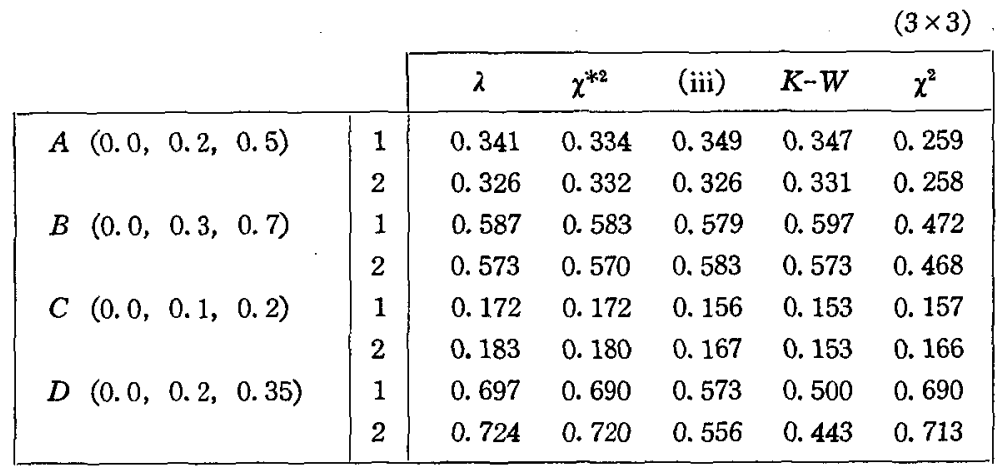

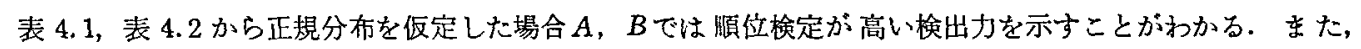
$\lambda, \chi^{* 2}$ もほぼ同程度の検出力を持つ. 㷌無仮説からのズレを全方向で捕党る適合度カイ二乘検定は予想通り检

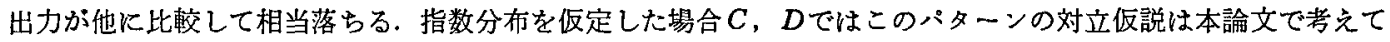
いる対立仮説の凸錐の境界にあるため，中央付近（正規分布仮定が対応）で高い検出力を持つよらに構成された

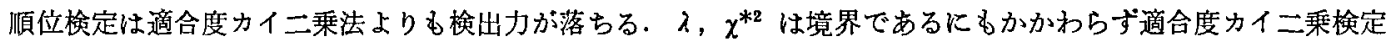
之同程度の検出力を保持する.

[I] $4 \times 4$ の 2 元表に対して

[I ] の $3 \times 3$ の場合と同棣に対立仮説のモデルを設定する. 
表 4.2 シュミレーションでの検出カ $(n . .=100$, 繰り返し 5000 回 $)$

\begin{tabular}{|c|c|c|c|c|c|c|}
\hline & & \multicolumn{5}{|r|}{$3 \times 3$} \\
\hline & & $\lambda$ & $\chi^{* 2}$ & (iii) & $K-W$ & $\chi^{2}$ \\
\hline$A(0.0,0.2,0.5)$ & 1 & $\begin{array}{l}0.350 \\
(0.009)\end{array}$ & $\begin{array}{l}0.339 \\
(0.009)\end{array}$ & $\begin{array}{l}0.356 \\
(0.009)\end{array}$ & $\begin{array}{l}0.353 \\
(0.009)\end{array}$ & $\begin{array}{l}0.268 \\
(0.009)\end{array}$ \\
\hline & 2 & $\begin{array}{l}0.327 \\
(0.008)\end{array}$ & $\begin{array}{l}0.327 \\
(0.008)\end{array}$ & $\begin{array}{l}0.328 \\
(0.008)\end{array}$ & $\begin{array}{l}0.328 \\
(0.008)\end{array}$ & $\begin{array}{l}0.246 \\
(0.007)\end{array}$ \\
\hline$B(0.0,0.3,0.7)$ & 1 & $\begin{array}{l}0.584 \\
(0.009)\end{array}$ & $\begin{array}{l}0.578 \\
(0.009)\end{array}$ & $\begin{array}{l}0.579 \\
(0.009)\end{array}$ & $\begin{array}{l}0.596 \\
(0.009)\end{array}$ & $\begin{array}{l}0.478 \\
(0.010)\end{array}$ \\
\hline & 2 & $\begin{array}{l}0.575 \\
(0.008)\end{array}$ & $\begin{array}{l}0.570 \\
(0.008)\end{array}$ & $\begin{array}{l}0.579 \\
(0.008)\end{array}$ & $\begin{array}{l}0.569 \\
(0.008)\end{array}$ & $\begin{array}{l}0.472 \\
(0.009)\end{array}$ \\
\hline$C(0.0,0.1,0.2)$ & 1 & $\begin{array}{l}0.171 \\
(0.006)\end{array}$ & $\begin{array}{l}0.172 \\
(0.006)\end{array}$ & $\begin{array}{l}0.155 \\
(0.006)\end{array}$ & $\begin{array}{l}0.153 \\
(0.006)\end{array}$ & $\begin{array}{l}0.160 \\
(0.006)\end{array}$ \\
\hline & 2 & $\begin{array}{l}0.180 \\
(0.006)\end{array}$ & $\begin{array}{l}0.179 \\
(0.006)\end{array}$ & $\begin{array}{l}0.164 \\
(0.006)\end{array}$ & $\begin{array}{l}0.151 \\
(0.005)\end{array}$ & $\begin{array}{l}0.168 \\
(0.005)\end{array}$ \\
\hline$D(0.0,0.2,0.35)$ & 1 & $\begin{array}{l}0.699 \\
(0.009)\end{array}$ & $\begin{array}{l}0.694 \\
(0.009)\end{array}$ & $\begin{array}{l}0.559 \\
(0.010)\end{array}$ & $\begin{array}{l}0.495 \\
(0.010)\end{array}$ & $\begin{array}{l}0.686 \\
(0.010)\end{array}$ \\
\hline & 2 & $\begin{array}{l}0.736 \\
(0.007)\end{array}$ & $\begin{array}{l}0.733 \\
(0.007)\end{array}$ & $\begin{array}{l}0.581 \\
(0.009)\end{array}$ & $\begin{array}{l}0.471 \\
(0.009)\end{array}$ & $\begin{array}{l}0.726 \\
(0.008)\end{array}$ \\
\hline
\end{tabular}

（）内は標準偏差

$a=4$ のとき

case $1: p_{1 j}=q_{1 j} / 4, p_{2 j}=q_{2 j} / 4, p_{3 j}=q_{3 j} / 4, p_{4 j}=q_{4 j} / 4$

case $2: p_{1 j}=q_{1 \mathrm{~g}} / 10, p_{2 \mathrm{~g}}=q_{2 \mathrm{~J}} / 5, p_{3 \mathrm{j}}=0.3 q_{3 \mathrm{~g}}, p_{4 \mathrm{~g}}=0.4 q_{4 \mathrm{~g}}$

また，対立仮説のモデルに用いる $\mu_{i} ， \mu_{i}^{\prime}$ は次のよらにする.

$A$ (正規分布仮定) $\quad \mu=(0.0,0.2,0.4,0.6)$

表 4.3 シュミレーションでの検出力 $(n . .=240$, 繰り返し 5000回 $)$

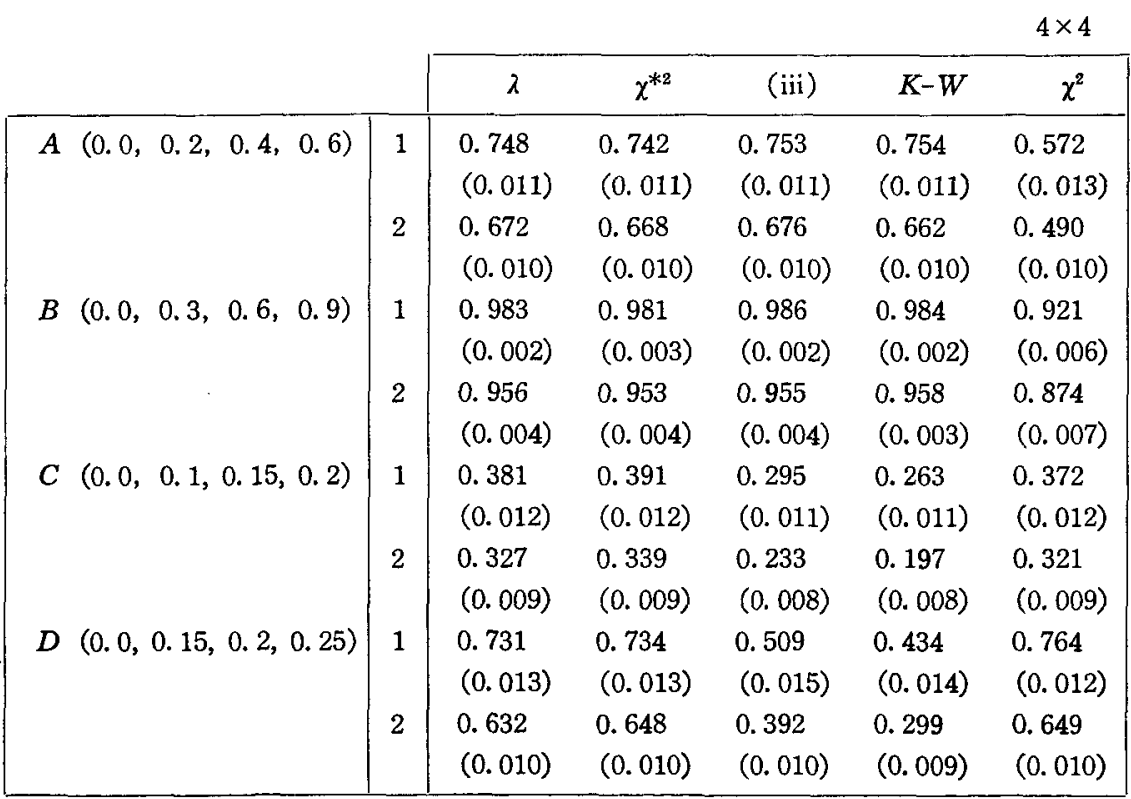

（）内は標準偏差 


$$
\begin{array}{ll}
B \text { (正規分布仮定) } & \mu=(0.0,0.3,0.6,0.9) \\
C \text { (指数分布仮定) } & \mu^{\prime}=(0.0,0.1,0.15,0.2) \\
D \text { (指数分布仮定) } & \mu^{\prime}=(0.0,0.15,0.2,0.25)
\end{array}
$$

比較した統計量は $[\mathrm{I}]$ の場合と同じで，(iii）の順位検定は $s=(4,3,2,1)$ とした。

乱数を使ったシミュレーションによる検出力が表 4.3 である.ただし $n .=240$. この場合も $[1]$ と同様な傾 向がみられる，指数分布を仮定した場合，ス-法が累皘カイ二乗法よりる1\%程度検出力が落ちるのは裹却限界值 を求める際の補間の段階で直線近似をしたことによって值が少し大きめに求められたためである.

\section{5. 考察}

カテゴリーに順序がある場合累䡠カイ二乗法が高い検出力を持つことは知られていたが本論文の検討もそれを 支持している.また同時にここで考劣てきた とといら統計量も累積カイ二乘法と同等の検出力を持つことる実証 された．多重比較における利用と併せて考えれば，一方に順序のある場合の仮説検定には有用であると考只られ る. ただし，累積カイ二乗法の㷌無仮説の下でのパーセント点は修正されたカイ二乗分布で近似されるのに対し

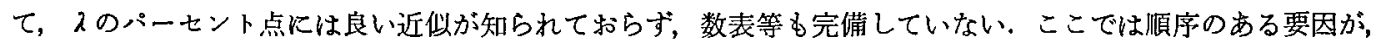
3 水準, 4 水準の 2 つの場合に限りパーセント点を求めた．この先数表等の整備が望まれるが，本論文のアプロ ーチではできるとしても 5 水準が限度と思われる。これに代る力法としては分布関数の漸近展開による方法など が考えられるが，今後の研究を待ちたい．

なお，本法の具体的な応用例については触れなかったので広进 [7]，[8]，等を参照して欲しい。

最後に査読者らからは zonal 多項式を用いない方法についての示唆をはじめ原稿の不備を種々ご指摘いただ きました。ここに謝意を表します。

\section{References}

[1] James, A.T. (1964): Distribution of matrix variates and latent roots derived from normal samples. Ann. Math. Statist., 35, 475-501.

[2] James, A.T. (1966): Inference on latent roots by calculation of hypergeometric functions of matrix argument. Mult. Ann., 209-235, Edited by Krishnaiah.

[3] James, A.T. (1968) : Calculation of Zonal polynomial coefficients by use of the Laplace-Beltrami operator. Ann. Math. Statist., 39, 1711-1718.

[4] Sugiyama, T. (1972) : Percentile points of the largest latent root of a matrix and power calculations for testing hyphothesis $\Sigma=I$. Journ. Japan Statist. Soc., 3, 1-8.

[5] 会田雅人 (1983)：多項分布に関する順序制約下での推測方式の研究, 東京大学工学部計数工学科修士 論文.

[6]竹内啓・広津千尋（1978）：計数データ汇関する累積カイ二乗法. 応用統計学，8，39-50.

〔7〕広津千寻 (1982)：離散データ解析. 教育出版，東京.

〔8〕広津千蕁 (1983)：種々の離散モデルにおける要因分析. 応用統計学会第 5 回シンボジム予稿集. 